Analysis

\title{
Balancing the use of wetlands for economic well-being and ecological security: The case of the Limpopo wetland in southern Africa
}

\author{
Wellington Jogo ${ }^{\text {a,* }}$, Rashid Hassan ${ }^{\mathrm{b}}$

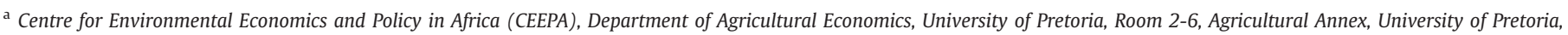 \\ Pretoria 0002, South Africa \\ b Centre for Environmental Economics and Policy in Africa (CEEPA), Department of Agricultural Economics, University of Pretoria, South Africa
}

\section{A R T I C L E I N F O}

\section{Article history:}

Received 29 September 2009

Received in revised form 30 January 2010

Accepted 27 February 2010

Available online xxxx

\section{Keywords:}

Wetlands

Southern Africa

Ecological-economic model

Economic well-being

\begin{abstract}
A B S T R A C T
Wetlands in southern Africa continue to be degraded and lost through conversion to agriculture and other uses. One of the major constraints to sustainable management of wetlands in the region is that wetland users and decision-makers have insufficient understanding of the consequences of alternative management and policy regimes on wetland functioning, ecosystem services and human well-being. This study developed an ecological-economic model based on the system dynamics framework to simulate the impacts of alternative policy regimes on wetland functioning and economic well-being. Results showed that wetland services (crop production and natural resource harvesting) are inter-linked with trade-offs involved through their competition for labour, land and water resources. Policy scenario simulation results showed that diversifying livelihoods out of agriculture simultaneously improves economic well-being and enhances wetland conservation. Pure conservation strategies impose significant losses in the economic welfare of local population unless supported with diversification of livelihood sources. Government policies that support livelihood diversification into off-farm livelihood opportunities for the rural poor are critical for sustainable wetland management.
\end{abstract}

(c) 2010 Elsevier B.V. All rights reserved.

\section{Introduction}

Wetlands are found throughout southern Africa. However, due to lack of comprehensive national wetland inventories characterising and classifying wetlands in a systematic manner, the exact extent of wetlands in the region is unknown (Taylor et al., 1995; Frenken and Mharapara, 2002). In the Limpopo basin, it is estimated that $3 \%$ of the total land area is under wetlands (World Resources Institute, 2003) although this figure differs across studies due to differences in wetland definition and delineation methods. Swamps and floodplains are the most widespread type of wetlands in the region.

Wetlands play a significant role in the livelihoods of rural communities in southern Africa (Taylor et al., 1995; Breen et al., 1997; Turpie et al., 1999; Frenken and Mharapara, 2002). The ability of wetlands to store water during the wet season and release it during the dry season provides farmers living in semi-arid areas opportunities to grow crops all-year round thereby improving their food security and incomes. Besides crop production, wetlands provide other services that support human welfare such as livestock grazing and watering, water supply, fishing and natural products (Matiza and Chabwela, 1992).

\footnotetext{
* Corresponding author. Fax: +27 124204958.

E-mail address: frankjogo@yahoo.com (W. Jogo).
}

Several studies quantified the economic values of wetland systems in southern Africa (e.g. Turpie et al., 1999; Seyam et al., 2001; Schuyt, 1999). However, it is worth noting that most of these studies were carried out at local levels due to limited data on the actual extent of wetlands at national and regional levels. In addition, most of the valuation studies focused on quantifying a few key services as some wetland services are difficult to quantify given the data and resource limitations. For example, Seyam et al. (2001) used a simple approach that takes into account the common problem of data limitations and estimated that the total use value of the Zambezi basin wetlands was US\$123 million per year, which was equivalent to 4\% of Zambia's GDP in 1990. Adekola (2007) estimated that the direct use value of the main provisioning services of the Ga-Mampa wetland is US\$90 000 per year.

Despite their values, wetlands are very fragile ecosystems threatened by human interventions. Altering the wetland environment through conversion to cropland and other uses can potentially degrade wetlands and undermine their capacity to provide services in the future. As in many other parts of the world, wetlands in southern Africa are being increasingly degraded and lost mainly through conversion to cropland (Matiza and Chabwela, 1992; Breen et al., 1997; Biggs et al., 2004). For example, Kotze et al. (1995) estimated that more than half of the wetland area in South Africa has been lost. In a review of wetland inventories in southern Africa, Taylor et al. (1995) reported wetland losses in two areas in Natal, South Africa - the Tugela basin where over $90 \%$ of the wetland area has been lost in parts 
of the basin and the Mfolozi catchment where 58\% of the original wetland area has been lost. Sarron (2005) estimated that approximately half of the Ga-Mampa wetland (the case study wetland system selected for this study) was converted to agriculture between 1996 and 2004. This has been driven primarily by population growth and increasing frequency of droughts which are increasing demand for wetland services. Given the importance of the direct and ecological services wetlands provide to human society it is important that they are sustainably managed so that they continue to provide services in the future.

One of the major constraints to sustainable management of wetlands in the region is that wetland users and decision-makers have insufficient understanding of the consequences of alternative management and policy regimes on wetland functioning, ecosystem services and human well-being. To the best of the authors' knowledge, very little empirical knowledge of the impacts of alternative wetland management and policy regimes on wetland functioning, ecosystem services and human well-being is currently available in southern Africa. This is particularly the case with modeling multiple benefits from an ecosystem to enable evaluation of trade-offs between provisions of various components of the bundle of multiple services provided. This study aims to develop an empirical model establishing the linkages between ecological and economic components of a wetland system and apply the developed model to evaluate impacts of alternative policy and management regimes on wetland functioning, ecosystem services' supply and human well-being. The Limpopo wetland of southern Africa has been selected as the case study area.

The following section reviews relevant literature and presents the analytical framework and Section 3 describes the wetland system in the study area. Components of the empirical model and assumptions behind their specification are discussed in Section 4. Section 5 presents model parameters and performs model validation. Policy and management simulations' results are discussed in Sections 6 and 7 concludes the study and derives policy implications.

\section{The Analytical Framework}

This study attempts to develop an ecological-economic model based on systems' dynamics framework. The said framework takes into consideration feedback effects between ecological and economic systems as well as involved trade-offs in the supply of individual constituents of the bundle of multiple services provided by wetlands. This framework also captures inter-temporal effects of interventions on ecosystem dynamics.

The system dynamics' framework is based on systems theory which was developed during the mid-1950s by Forrester as an approach to understand dynamic behaviour of complex systems (Forrester, 1968). This approach recognises that elements of complex systems are tightly interwoven into one system with direct linkages and feedbacks between them. Although the framework was originally developed for understanding dynamics of industrial processes, it has been widely applied to analyze the dynamic behaviour of ecosystems (e.g. van Beukering et al., 2003; Portela and Rademacher, 2001; Higgins et al., 1997). The framework has also been widely applied to study wetland ecosystem dynamics (e.g. Chopra and Adhikari, 2004; Eppink et al., 2004; Güneralp and Barlas, 2003).

Our adapted framework consists of five subsystems: socioeconomic, wetland hydrology, natural wetland vegetation, crop production and land use change trade-offs. These subsystems are inter-linked such that changes in one subsystem impact on others with feedbacks among them (Fig. 1). For example, wetland hydrological processes influence the productivity of cultivated crops and natural wetland biomass, which in turn impact on human well-being and also have feedback influences on the wetland hydrology.

Crop and livestock production and the natural wetland vegetation subsystems also compete for land and labour resources. For example conversion of the wetland for crop production reduces the wetland area and consequently availability of its natural products including vegetation for livestock grazing. There are therefore trade-offs involved between these activities, which also require the use of labour and other inputs supplied by the communities and hence the competition for these inputs.

The crop, livestock and natural vegetation subsystems are linked to the wetland hydrological module through changes in water use. Crop and livestock activities abstract water from the wetland thereby affecting the wetland system's hydrology and water budget. The land use change component models the inter-temporal dynamics of the wetland and irrigated systems due to land use changes as the wetland is converted to cropland.

A positive relationship between growth in biomass of natural wetland vegetation and wetland groundwater level links natural wetland vegetation to the underlying hydrological system and captures trade-offs between crop and biomass production due to competition for water. For instance, as groundwater levels are lowered through wetland conversion to agriculture, natural wetland vegetation is adversely affected by competition with non-wetland plant species (Eppink et al., 2004). As biomass increases the actual growth rate is expected to decrease due to competition for limited resources (e.g. light, water, nutrients and space). This is also true the other way around, when biomass is removed from the wetland (e.g. through biomass harvesting) the actual growth rate will increase.

The economic welfare component of the system is influenced by benefits derived from exploiting the wetland ecosystem (i.e. crop, livestock and natural products, and domestic water supply) and income derived from other sources (i.e. off-farm employment and social transfers). This socio-economic subsystem on the other hand supplies labour and other inputs for which various crop, livestock, natural product harvesting and off-farm activities compete.

\section{The Wetland System under Study: The Limpopo Wetland}

This study was carried out in the Ga-Mampa wetland, which lies in the middle part of the Limpopo River basin in South Africa. The wetland is a riverine system covering an area of approximately 120 ha (Kotze, 2005). It lies in the former homeland ${ }^{1}$ area of Lebowa in the Capricorn district of the Limpopo province. This area is characterised by seasonal rainfall and experiences frequent droughts. Approximately 2800 people (394 households) reside in the vicinity of the wetland and partly depend on the services provided by the wetland for their livelihood. A significant proportion of the local population use the wetland for crop production due to its ability to store moisture during the dry season and inherently fertile soils which make it possible for farmers to produce crops throughout the year. The use of the wetland for crop production is a mechanism by which many households in the study area mitigate the risk of crop losses in drought periods.

Agricultural activities have extensively modified the ecological status of the wetland system under study. Sarron (2005) estimated that between 1996 and 2004 half the wetland (about 60 ha) had been converted to cropland. By 2006, the wetland area converted to agriculture had grown to about 66 ha (Adekola, 2007). The hydrology of the wetland has also been adversely affected by artificial drainage of water by wetland farmers aimed at removing excess water to create favourable growing conditions for maize, the main crop grown in the wetland.

\footnotetext{
1 These are also termed native reserves or tribal lands which were delineated under the Natives Land Act of 1913 (Wickins, 1981) for black people and are typically located in marginal areas with low rainfall, less fertile soils and lack of access to basic services such as water and education facilities.
} 


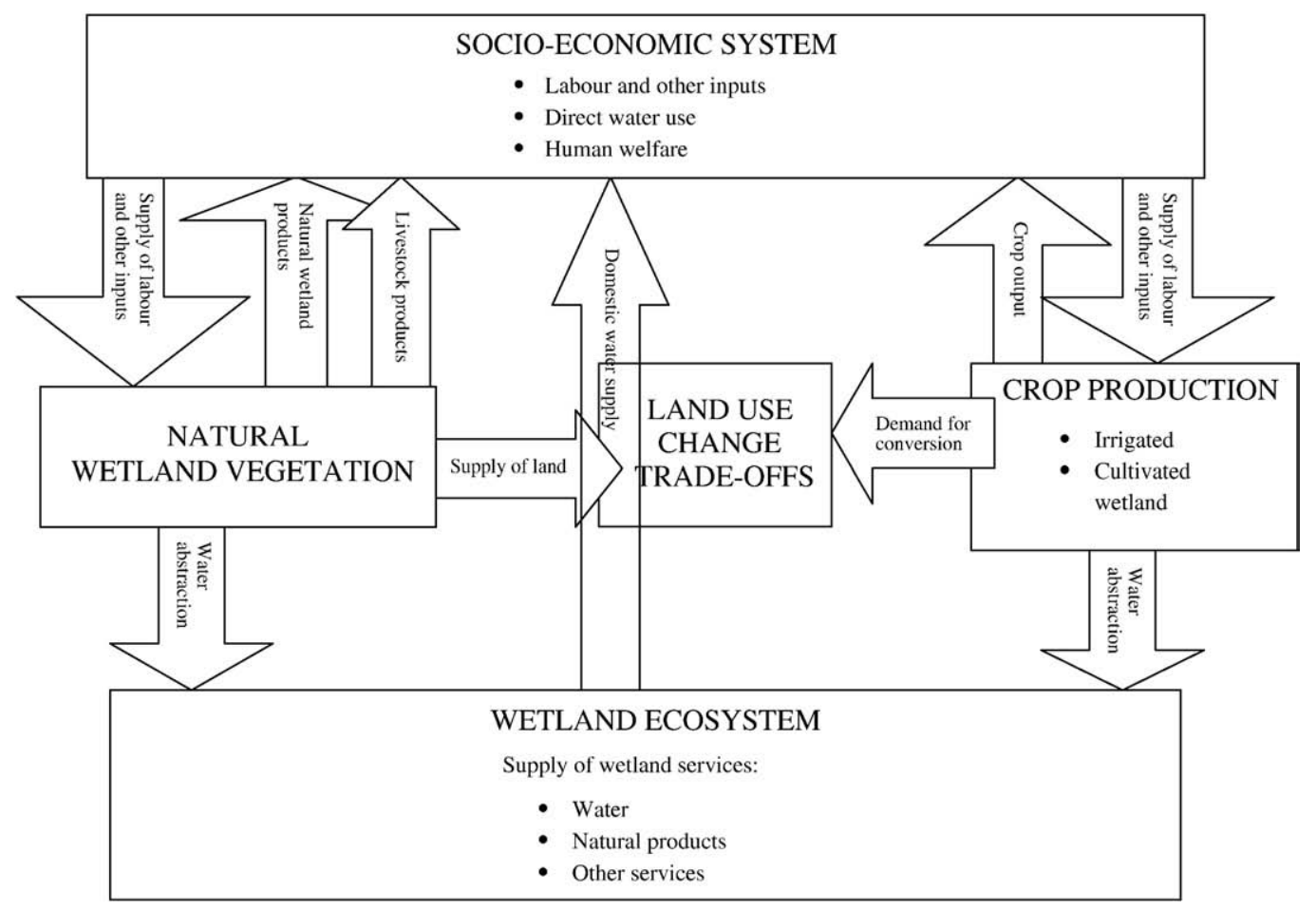

Fig. 1. Analytical framework showing the interactions between components of the system. Adapted from Güneralp and Barlas (2003).

Besides crop production, the wetland provides other services that support people's livelihoods such as dry season livestock grazing and watering, domestic water supply, fishing and natural products (reeds, sedge and edible plants). Table 1 shows the estimated number of households using the wetland for different services and the estimated economic values per household for each service. Results from a study by Adekola (2007) showed that the annual net financial value of these services is US\$211 per household with crop production contributing the highest to total financial value of the wetland with an estimated value per household of US\$1072 per annum. The same study showed that the wetland contributes a cash income of US\$35 per household per annum with sedge harvesting contributing the highest to household cash income compared to all the other services.

Table 1

Number of households using wetland for the different uses and estimated values per household.

Source: Household survey data and Adekola (2007).

\begin{tabular}{llll}
\hline Wetland use & $\begin{array}{l}\text { Number of } \\
\text { households in } \\
\text { sample } \\
(\mathrm{n}=143)\end{array}$ & $\begin{array}{l}\text { Net financial value of } \\
\text { service per user } \\
\text { household } \\
\text { (US\$/household/annum) }\end{array}$ & $\begin{array}{l}\text { Cash income per } \\
\text { user household (US\$/ } \\
\text { household/annum) }\end{array}$ \\
\hline $\begin{array}{l}\text { Edible } \\
\text { plant collection }\end{array}$ & $80(56)$ & 84 & 2 \\
$\begin{array}{l}\text { Livestock } \\
\text { grazing }\end{array}$ & $66(46)$ & 192 & 0 \\
$\begin{array}{l}\text { Crop production } \\
\text { Domestic water }\end{array}$ & $60(42)$ & 1072 & 10 \\
$\quad 37(26)$ & 9 & 0 \\
$\begin{array}{l}\text { Reed collection } \\
\text { Sedge collection }\end{array}$ & $34(24)$ & 93 & 4 \\
$\begin{array}{c}\text { Firewood } \\
\text { collection }\end{array}$ & $2(1.4)$ & 667 & 20 \\
Fishing & $5(3.5)$ & 12 & 0 \\
No use & $11(8)$ & - & 0 \\
\hline
\end{tabular}

Figures in parenthesis are percentages.

a Values for livestock grazing are unreliable as data for this service was limited.

\section{The Empirical Model Components and Assumptions}

Although the wetland system under study provides several direct services, crop production and natural products harvesting are the most important services ${ }^{2}$ supporting the well-being of the local population (Adekola, 2007). Therefore, our empirical model focuses on these two services. The model integrates five modules which are discussed in detail below. The full system of equations of our ecological-economic wetland model is presented in Appendix A and model variables to solve for endogenously are defined in Table 2.

\subsection{Hydrology Module}

Our wetland hydrological system comprises of five linked subsystems: the upper catchment, the hill slopes, the irrigation scheme, the wetland aquifer, and the river system (Fig. 2). The wetland is fed primarily by recharge from precipitation and irrigation scheme, losses through evapotranspiration from crops and natural vegetation and outflow of ground water from the wetland to the river through seepage (McCartney, 2005).

The hydrological module is represented by the four equations' system given in Appendix A (Eq. (1) to Eqs. (4a) and (4b)) determining the wetland soil water balance with explicit links to water use by cultivated and natural vegetation. In addition, changes in the wetland soil water balance influence wetland groundwater level through recharge (Eq. (4b)).

\subsection{Crop Production Module}

To estimate crop water use we employ a linear crop yield-water response function (Eq. (5) in Appendix A) based on the CROPWAT ${ }^{3}$ model developed by FAO (Doorenbos and Kassam, 1979). A reduced form household grain supply function (Eq. (6) of Appendix A) derived

\footnotetext{
${ }^{2}$ Livestock production and domestic water supply activities have been excluded from the empirical model due to lack of necessary information (see Jogo, 2009).

${ }^{3}$ http://www.fao.org/ag/AGL/aglw/cropwat.stm.
} 
Table 2

Definition of endogenous model variables.

\begin{tabular}{|c|c|c|}
\hline Variable & Definition & Units \\
\hline $\mathrm{ET}_{\mathrm{t}}^{\mathrm{i}}$ & Total evapotranspiration for system $\mathrm{i}(\mathrm{i}=$ wetland or irrigation system) at time $\mathrm{t}$ & Millimetres \\
\hline $\mathrm{ETc}_{\mathrm{t}}^{\mathrm{i}}$ & Actual total crop evapotranspiration from cultivated area from system $\mathrm{i}(\mathrm{i}=$ wetland or irrigation system) at time $\mathrm{t}$ & Millimetres \\
\hline $\mathrm{ET}_{\mathrm{a}}^{\mathrm{i}}$ & Actual crop evapotranspiration per ha of cultivated area in system i ( $\mathrm{i}=$ wetland or irrigation system) & Millimetres \\
\hline $\mathrm{ET}_{\mathrm{v}}^{\mathrm{w}}$ & Actual evapotranspiration from natural wetland vegetation & Millimetres \\
\hline $\mathrm{GWL}_{\mathrm{t}}$ & Wetland groundwater level at time $t$ & Metres \\
\hline $\mathrm{GS}_{\mathrm{t}}$ & Groundwater discharge from wetland at time $t$ & Millimetres \\
\hline $\mathrm{CR}_{\mathrm{t}}$ & Capillary rise at time $\mathrm{t}$ & Millimetres \\
\hline$\Delta S^{\mathrm{w}}$ & Change in wetland water storage ( $\mathrm{w}=$ wetland) & Cubic millimetres \\
\hline $\mathrm{MC}_{\mathrm{t}}$ & Wetland soil water content & Millimetres \\
\hline $\mathrm{TA}_{\mathrm{t}}^{\mathrm{w}}$ & Total wetland area at time $t$ & Hectares \\
\hline$A C_{t}^{i}$ & Area cultivated of system $\mathrm{i}$ at time $\mathrm{t}(\mathrm{i}=$ wetland or irrigation system) & Hectares \\
\hline$Y_{a}^{i}$ & Actual crop yield ( $\mathrm{i}=$ wetland or irrigation system) & Tons/ha \\
\hline $\mathrm{G}_{\mathrm{q}, \mathrm{t}}$ & Household grain supply at time $t$ & $\mathrm{~kg} / \mathrm{household} /$ year \\
\hline $\mathrm{L}_{\mathrm{G}, \mathrm{t}}$ & Household labour used in grain production at time $t$ & Hours/household/year \\
\hline $\mathrm{TG}_{\mathrm{t}}^{\mathrm{i}}$ & Total grain supply from system $\mathrm{i}(\mathrm{i}=$ wetland or irrigation system $)$ at time $\mathrm{t}$ & Tons/year \\
\hline $\mathrm{R}_{\mathrm{t}}$ & Net value of grain at time $t$ & Rands/year \\
\hline $\mathrm{B}_{\mathrm{t}}$ & Biomass per ha at time $t$ & Tons/ha \\
\hline$V_{t}$ & Net value of harvested biomass at time $t$ & Rands/year \\
\hline $\mathrm{s}_{\mathrm{t}}$ & Intrinsic growth rate at time $\mathrm{t}$ & Non-dimensional \\
\hline $\mathrm{r}_{\mathrm{t}}$ & Actual growth rate at time $t$ & Non-dimensional \\
\hline$\sigma_{\mathrm{t}}$ & Growth rate multiplier at time $t$ & Non-dimensional \\
\hline $\mathrm{TB}_{\mathrm{t}}$ & Total biomass stock at time $t$ & Tons \\
\hline $\mathrm{h}_{\mathrm{t}}$ & Total biomass harvested at time $\mathrm{t}$ & Tons \\
\hline $\mathrm{NH}_{\mathrm{t}}$ & Number of biomass harvesters at time $t$ & Households \\
\hline $\mathrm{X}_{\mathrm{H}, \mathrm{t}}^{\mathrm{H}}$ & Household biomass supply at time $t$ & Tons/household/year \\
\hline$b_{t}$ & Labour costs for biomass harvesting at time $t$ & Rands/year \\
\hline $\mathrm{L}_{\mathrm{H}, \mathrm{t}}$ & Household labour used in biomass harvesting at time $t$ & Hours/household/year \\
\hline Pop $_{t}$ & Population at time $\mathrm{t}$ & People \\
\hline $\mathrm{EM}_{\mathrm{t}}$ & Number of emigrants at time $t$ & People \\
\hline$e_{t}$ & Emigration rate at time $t$ & Non-dimensional \\
\hline $\mathrm{LS}_{\mathrm{t}}$ & Total labour supply at time $t$ & Hours/year \\
\hline $\mathrm{O}_{\mathrm{t}}$ & Off-farm income at time $\mathrm{t}$ & Rands/year \\
\hline $\mathrm{NO}_{\mathrm{t}}$ & Number of households engaged in off-farm work at time $t$ & Households \\
\hline $\mathrm{L}_{\mathrm{o}, \mathrm{t}}$ & Household labour time used in off-farm work at time t & Hours/household/year \\
\hline $\mathrm{LD}_{\mathrm{t}}$ & Total labour demand by livelihood activities at time $t$ & Hours/year \\
\hline $\mathrm{E}_{\mathrm{t}}$ & Exogenous income at time $\mathrm{t}$ & Rands/year \\
\hline$z_{t}$ & Social grant rate at time $t$ & Rands/year \\
\hline $\mathrm{NI}_{\mathrm{t}}$ & Total net income at time $\mathrm{t}$ & Rands/year \\
\hline $\mathrm{SW}_{\mathrm{t}}$ & Human well-being at time $t$ & Rands/capita \\
\hline
\end{tabular}

from an agricultural household model (see Jogo, 2009) is then linked to the crop yield-water response function using a two-step process. First, household grain supply and area cultivated are aggregated across all households in irrigated and wetland systems to get total grain supply and area cultivated in both systems as given in Eq. (8) of Appendix A. The second step computes average yield ( $\mathrm{Y}_{\mathrm{a}}$ in Eq. (9)) which is substituted for actual yield in Eq. (5) to compute crop water use $\left(\mathrm{ET}_{\mathrm{a}}\right)$.

Two input demand functions are included in specification of the grain supply system: water and labour. Crop water use obtained from Eq. (5) is used as the proxy for quantity of water used in wetland grain production. As the actual quantity of water used for irrigated maize production is difficult to determine since the irrigation system in the study area uses gravity to convey water directly from the river into the fields through canals the $\mathrm{ET}_{\mathrm{a}}$ for maize grain under irrigation is used as an alternative. Since rain water is not supplied by an economic agent at a cost, price of water used in dryland maize production does not exist. We accordingly used water tariff figures for agricultural water in South Africa for 2009 (http://www.dwaf.gov.za) to attach a cost to water ( $\mathrm{P}_{\mathrm{w}}$ ).

Labour demand for grain is specified in Eq. (7) of Appendix A. The labour costs for grain production are computed by multiplying the amount of labour time used in grain production (which is estimated based on reduced form labour use equation derived from an agricultural household model presented in Jogo, 2009) by the ruling wage rates.

\subsection{Land Use Change Module}

This module captures the dynamics of changes in area cultivated with grains under wetlands and under irrigation. Based on informa- tion from key informant interviews in the study area irrigated area is assumed to be constant over time and is estimated to be equal to 138 ha (Chiron, 2005). However, the area of wetland converted to cultivation grows over time as the natural wetland area is cleared for crop production causing the total wetland area to decline. Changes in the area of wetland converted to cultivation is a function of three sets of factors: (i) changes in population which increase consumption demand for food grain (ii) crop output prices and input prices which provide incentives (or disincentive) to convert the wetland for crop production and (iii) decline in annual precipitation which results in new farmers moving into the wetland to cultivate because of its ability to retain soil moisture throughout the year.

To predict the effect of these factors (precipitation $-P_{t}$ ), agricultural prices for output $\left(\mathrm{P}_{\mathrm{G}, \mathrm{t}}\right)$ and inputs $\left(\mathrm{P}_{\mathrm{X}, \mathrm{t}}\right)$ and population $\left(\mathrm{Pop}_{\mathrm{t}}\right)$ on area of wetland cultivated $\left(A C_{t}^{\mathrm{w}}\right)$ we fitted historical annual time series data for these variables to past area cultivated in the wetland using multiple regression analysis as specified by Eq. (12) in Appendix A. Change in area of wetland under cultivation causes changes in the total wetland area as specified by Eq. (11) in Appendix A.

\subsection{Natural Wetland Vegetation Module}

This module describes the dynamics of wetland natural biomass. Reeds (Phragmites australis - Cav, and Phragmites mauritanus) are the major constituents of biomass in the studied wetland system (Kotze, 2005). Following Woodwell (1998) and Hellden (2008), a logistic growth model (s-shaped growth curve) is employed to model biomass growth dynamics. This assumes that the stock of biomass 


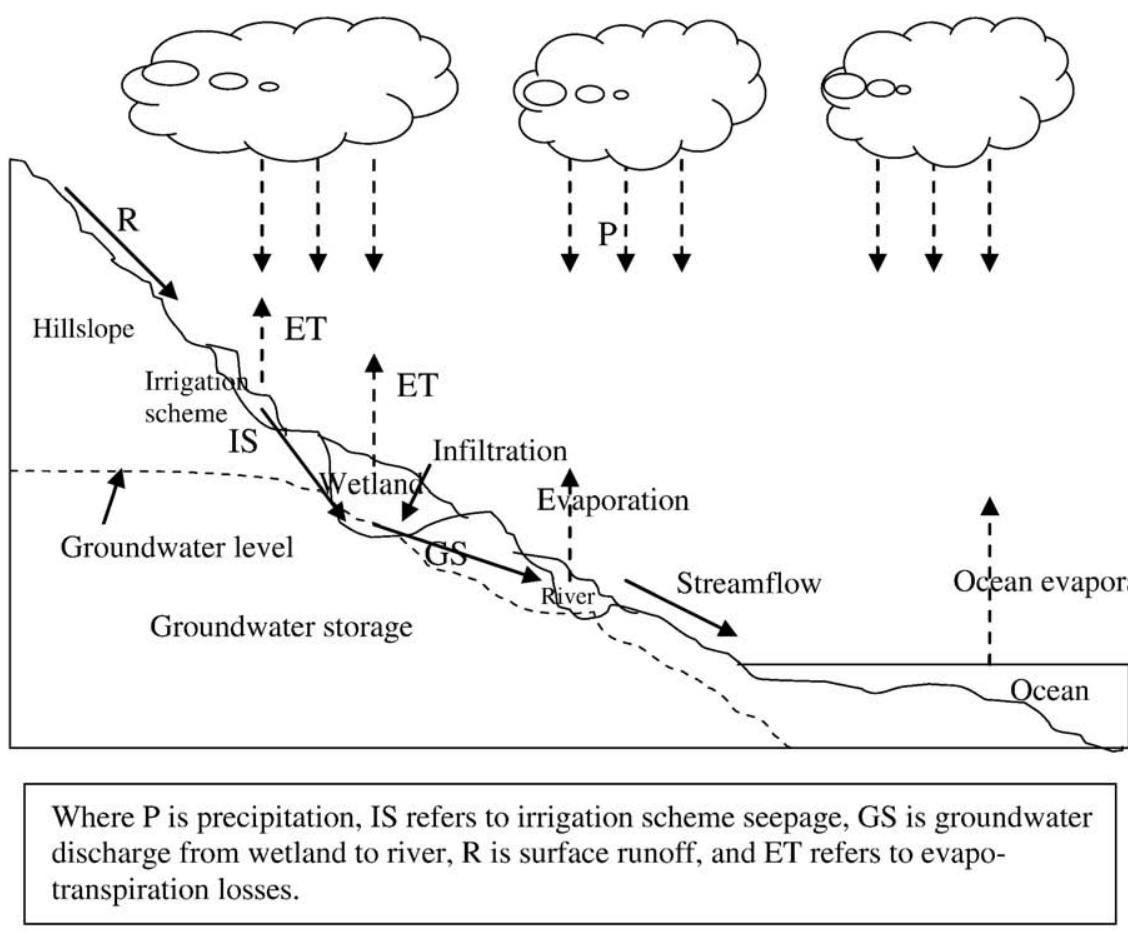

Fig. 2. Schematic representation of the main hydrological fluxes of the wetland. Adapted from Bullock and Acreman (2003).

per hectare $\left(B_{t}\right)$ of wetland area follows a logistic growth function as specified by Eq. (13) in Appendix A.

To capture the changes in actual growth rate as biomass stock changes we multiply the growth rate by a density dependent factor (or growth rate multiplier). The density dependent factor is equal to 1 (100\%) when biomass stock is close to zero and the rate decreases to close to zero when the stock is in full growth (Eq. (16)). This is based on the work of Hellden (2008) on the relationship between biomass stock and growth rates.

The quantity of wetland biomass harvested per household is given by the reduced form household biomass supply function (Eq. (20) in Appendix A) which is derived from an agricultural household model (see Jogo, 2009). Similarly, labour time spend on biomass harvesting is given by a biomass labour use reduced form equation (Eq. (22)) derived from the same agricultural household model.

The number of biomass harvesting households $\left(\mathrm{NH}_{\mathrm{t}}\right)$ varies over time and is influenced by the total biomass stock. We assume that number of harvesting households is positively related to total biomass stock, such that as total biomass stock declines, the number of biomass harvesting households declines as the effort required to meet required biomass needs increases (Eq. (19)).

\subsection{The Economic Well-being Module}

This module deals with the welfare of human population in the study area which influences demand for grain and natural products of the wetland for own consumption and sales for cash income. Communities living in the area also supply labour for these activities. Following Woodwell (1998) and Hellden (2008) this study used an exponential population growth function (Eq. (24) in Appendix A) where population growth is assumed to vary with the natural growth rate $g$ (birth and death rate) and out-migration EMt. Although both death and birth rates are dependent on a number of factors e.g. family policies, access to markets and health services, these are not considered in the model. We however, assume that emigration rate $\left(e_{t}\right)$ varies over time and is influenced by availability of off-farm employment opportunities (the proxy for this is GDP per capita) and rainfall (low rainfall reduces agricultural productivity resulting in more people migrating to urban areas to seek off-farm income opportunities). Population in the study area is accordingly assumed to grow with GDP per capita and rainfall as given in Eq. (26) in Appendix A.

This module also derives the value of services of the wetland ecosystem and income from different sources. Four main sources of income are considered in the model: net value of grain production (Eq. (10)), net value of biomass harvested (Eq. (23)); off-farm wage income (Eq. (30)) and exogenous income (income from government social grants - Eq. (33)). ${ }^{4}$ Total net income which is the summation of the four forms of income (Eq. (35)) is divided by total population to get net income per capita which is our measure (index) of economic well-being (Eq. (36)).

\section{Specification of Model Parameters and Validation}

Table 3 presents values of parameters and provides initial values of exogenous variables of the specified model and their sources. Parameters of the hydrological module specified above are obtained from Durand (2008) and Chiron (2005).

It is assumed that local production and agricultural input demand levels are too small to influence market prices therefore grain output and input prices are assumed exogenous. As local level time series data on grain (maize) producer prices that take into account location differences and transport costs is limited we resorted to using national statistics (Department of Agriculture, 2009) for valuing maize output.

The total area of the studied wetland system was 54 ha in 2006 (Adekola, 2007). Wetland biomass per hectare was set to a maximum of 70 tons per annum which is the maximum annual productivity of reeds (Finlayson and Moser, 1991 cited in Turpie et al., 1999). As the productivity of reeds is positively related to ground water level, we assume that the intrinsic growth rate of wetland biomass is not constant and ranges between 0.3 and 0.4 and is positively related to wetland groundwater level as demonstrated by water depth-reeds growth correlations done by Tarr et al. (2004).

\footnotetext{
${ }^{4}$ Crop income and natural resource income give the net value of all production and harvested biomass at market prices including production or harvest sold or consumed.
} 
Table 3

Values of model parameters and their sources.

\begin{tabular}{|c|c|c|c|}
\hline Parameter label & Symbol & Value & Source \\
\hline Crop yield response to water factor for maize & $\mathrm{k}_{\mathrm{y}}$ & 1.25 & Durand (2008) \\
\hline Constant in the grain supply function & $\alpha_{0}$ & -2.19 & Jogo (2009) \\
\hline $\begin{array}{l}\text { Coefficient for exogenous income in the grain } \\
\text { supply function }\end{array}$ & $\alpha_{1}$ & 0.01 & Jogo (2009) \\
\hline Coefficient for wage rate in the grain supply function & $\alpha_{2}$ & -0.013 & Jogo (2009) \\
\hline Coefficient for price of grain in the grain supply function & $\alpha_{3}$ & 0.06 & Jogo (2009) \\
\hline $\begin{array}{l}\text { Coefficient for price of wetland biomass in the grain } \\
\text { supply function }\end{array}$ & $\alpha_{4}$ & -0.01 & Jogo (2009) \\
\hline $\begin{array}{l}\text { Coefficient for price of market goods in the grain } \\
\text { supply function }\end{array}$ & $\alpha_{5}$ & -0.08 & Jogo (2009) \\
\hline $\begin{array}{l}\text { Coefficient for price of agricultural inputs in the grain } \\
\text { supply function }\end{array}$ & $\alpha_{6}$ & -0.08 & Jogo (2009) \\
\hline Constant in the labour use equation for grain production & $\beta_{0}$ & 4.63 & Jogo (2009) \\
\hline $\begin{array}{l}\text { Coefficient for exogenous income in the labour use for } \\
\text { grain production }\end{array}$ & $\beta_{1}$ & -0.016 & Jogo (2009) \\
\hline $\begin{array}{l}\text { Coefficient for wage rate in the labour use equation for } \\
\text { grain production }\end{array}$ & $\beta_{2}$ & -0.039 & Jogo (2009) \\
\hline $\begin{array}{l}\text { Coefficient for price of grain in the labour use equation } \\
\text { for grain production }\end{array}$ & $\beta_{3}$ & 0.054 & Jogo (2009) \\
\hline $\begin{array}{l}\text { Coefficient for price of wetland biomass in the labour use } \\
\text { equation for grain production }\end{array}$ & $\beta_{4}$ & -0.01 & Jogo (2009) \\
\hline $\begin{array}{l}\text { Coefficient for price of market goods in the labour use equation } \\
\text { for grain production }\end{array}$ & $\beta_{5}$ & -0.001 & Jogo (2009) \\
\hline $\begin{array}{l}\text { Coefficient for price of agricultural inputs in the labour use } \\
\text { equation for grain production }\end{array}$ & $\beta_{6}$ & -0.01 & Jogo (2009) \\
\hline Constant in the biomass supply function & $\theta_{0}$ & -1.62 & Jogo (2009) \\
\hline $\begin{array}{l}\text { Coefficient for exogenous income in the biomass } \\
\text { supply function }\end{array}$ & $\theta_{1}$ & -0.09 & Jogo (2009) \\
\hline Coefficient for wage rate in the biomass supply function & $\theta_{2}$ & -0.036 & Jogo (2009) \\
\hline $\begin{array}{l}\text { Coefficient for price of grain in the wetland biomass } \\
\text { supply function }\end{array}$ & $\theta_{3}$ & -0.13 & Jogo (2009) \\
\hline $\begin{array}{l}\text { Coefficient for price of biomass in the wetland biomass } \\
\text { supply function }\end{array}$ & $\theta_{4}$ & 0.01 & Jogo (2009) \\
\hline $\begin{array}{l}\text { Coefficient for price of market goods in the wetland biomass } \\
\text { supply function }\end{array}$ & $\theta_{5}$ & -0.37 & Jogo (2009) \\
\hline $\begin{array}{l}\text { Coefficient for price of agricultural inputs in the wetland biomass } \\
\text { supply function }\end{array}$ & $\theta_{6}$ & 0.11 & Jogo (2009) \\
\hline Constant in the labour use equation for wetland biomass harvesting & $\rho_{0}$ & 2.13 & Jogo (2009) \\
\hline $\begin{array}{l}\text { Coefficient for exogenous income in the labour use equation } \\
\text { for biomass collection }\end{array}$ & $\rho_{1}$ & -0.02 & Jogo (2009) \\
\hline $\begin{array}{l}\text { Coefficient for wage rate in the labour use equation for } \\
\text { biomass collection }\end{array}$ & $\rho_{2}$ & -0.086 & Jogo (2009) \\
\hline $\begin{array}{l}\text { Coefficient for price of grain in the labour use equation for } \\
\text { biomass collection }\end{array}$ & $\rho_{3}$ & -0.45 & Jogo (2009) \\
\hline $\begin{array}{l}\text { Coefficient for price of wetland biomass in the labour use } \\
\text { equation for biomass collection }\end{array}$ & $\rho_{4}$ & 0.02 & Jogo (2009) \\
\hline $\begin{array}{l}\text { Coefficient for price of market goods in the labour use } \\
\text { equation for biomass collection }\end{array}$ & $\rho_{5}$ & -0.12 & Jogo (2009) \\
\hline $\begin{array}{l}\text { Coefficient for price of agricultural inputs in the labour use } \\
\text { equation for biomass collection }\end{array}$ & $\rho_{6}$ & 0.34 & Jogo (2009) \\
\hline Constant in off-farm labour use equation & $\delta_{0}$ & -9.69 & Jogo (2009) \\
\hline Coefficient for exogenous income in off-farm labour use equation & $\delta_{1}$ & -0.74 & Jogo (2009) \\
\hline Coefficient for wage rate in off-farm labour use equation & $\delta_{2}$ & 0.014 & Jogo (2009) \\
\hline Coefficient for price of grain in off-farm labour use equation & $\delta_{3}$ & -0.12 & Jogo (2009) \\
\hline $\begin{array}{l}\text { Coefficient for price of wetland biomass in off-farm labour } \\
\text { use equation }\end{array}$ & $\delta_{4}$ & -0.01 & Jogo (2009) \\
\hline $\begin{array}{l}\text { Coefficient for price of market goods in off-farm labour use } \\
\text { equation }\end{array}$ & $\delta_{5}$ & -0.93 & Jogo (2009) \\
\hline $\begin{array}{l}\text { Coefficient for price of agricultural inputs in off-farm labour } \\
\text { use equation }\end{array}$ & $\delta_{6}$ & 0.64 & Jogo (2009) \\
\hline Natural population growth rate & $\mathrm{g}$ & 0.017 & Statistics South Africa (2004) \\
\hline $\begin{array}{l}\text { Constant in the number of people employed off-farm-GDP } \\
\text { per capita regression }\end{array}$ & $\mathrm{d}_{0}$ & -3.62 & $\begin{array}{l}\text { Regression analysis of number of people employed in off-farm } \\
\text { work and GDP per capita }\end{array}$ \\
\hline $\begin{array}{l}\text { Coefficient for GDP per capita effect on number of people } \\
\text { employed off-farm }\end{array}$ & $\mathrm{d}_{1}$ & 0.01 & $\begin{array}{l}\text { Regression analysis of number of people employed in off-farm work } \\
\text { and GDP per capita }\end{array}$ \\
\hline Constant in the emigration rate equation & $\mathrm{f}_{0}$ & -4.17 e $(-03)$ & $\begin{array}{l}\text { Multiple regression analysis of emigration rate, GDP per capita and } \\
\text { rainfall }\end{array}$ \\
\hline Coefficient for GDP per capita effect on emigration rate & $\mathrm{f}_{1}$ & $2.70 \mathrm{e}(-07)$ & Multiple regression analysis of emigration rate \\
\hline Coefficient for rainfall effect on emigration rate & $\mathrm{f}_{2}$ & $-6.9 e(-07)$ & Multiple regression analysis of emigration rate \\
\hline Coefficient for effect of CPI on social grant rate & $\mathrm{k}_{1}$ & 1.58 & Social grant rate-consumer price index regression analysis \\
\hline Constant for CPI effect on social grant rate & $\mathrm{k}_{0}$ & -48.35 & Social grant rate-consumer price index regression analysis \\
\hline Coefficient of rainfall in cultivated wetland area regression & $\mathrm{a}_{1}$ & -0.042 & $\begin{array}{l}\text { Multiple regression estimates of wetland cultivated area and } \\
\text { rainfall, grain price, agricultural input price and population }\end{array}$ \\
\hline Coefficient of grain price in cultivated wetland area regression & $\mathrm{a}_{2}$ & 0.021 & $\begin{array}{l}\text { Multiple regression estimates of wetland cultivated area and } \\
\text { rainfall, grain price, agricultural input price and population }\end{array}$ \\
\hline
\end{tabular}


Table 3 (continued)

\begin{tabular}{|c|c|c|c|}
\hline Parameter label & Symbol & Value & Source \\
\hline $\begin{array}{l}\text { Coefficient of price of agricultural input (seed maize) in the } \\
\text { cultivated wetland area regression }\end{array}$ & $a_{3}$ & -0.041 & $\begin{array}{l}\text { Multiple regression estimates of wetland cultivated area and } \\
\text { rainfall, grain price, agricultural input price and population }\end{array}$ \\
\hline $\begin{array}{l}\text { Coefficient of population in the cultivated wetland area } \\
\text { regression }\end{array}$ & $\mathrm{a}_{4}$ & 0.032 & $\begin{array}{l}\text { Multiple regression estimates of wetland cultivated area and } \\
\text { rainfall, grain price, agricultural input price and population }\end{array}$ \\
\hline $\begin{array}{l}\text { Proportion of working adults (aged } 15-64 \text { years) in the } \\
\text { population }\end{array}$ & $\kappa_{1}$ & 0.5 & Census data $(1996,2001)$ \\
\hline Proportion of children (aged 4-15 years) in the population & $\kappa_{2}$ & 0.3 & Census data $(1996,2001)$ \\
\hline Total labour supplied per adult per year $(\mathrm{h})$ & $\mathrm{m}_{1}$ & 1600 & Stephenne and Lambin (2001) \\
\hline Total labour supplied per child per year (h) & $\mathrm{m}_{2}$ & 800 & Stephenne and Lambin (2001) \\
\hline $\begin{array}{l}\text { Coefficient for biomass stock in the regression for number of } \\
\text { biomass harvesters }\end{array}$ & c & 0.0052 & $\begin{array}{l}\text { Regression analysis of number of biomass harvest and natural } \\
\text { wetland area historical time series data }\end{array}$ \\
\hline $\begin{array}{l}\text { Intercept term for the intrinsic growth rate for wetland } \\
\text { biomass }\end{array}$ & $\mu_{0}$ & 0.3 & Thenya (2006) \\
\hline $\begin{array}{l}\text { Coefficient of the effect of groundwater level on wetland } \\
\text { biomass growth rate }\end{array}$ & $\mu_{1}$ & 0.0001 & $\begin{array}{l}\text { Estimate based on reeds yield-water depth correlations by Tarr } \\
\text { et al. (2004) }\end{array}$ \\
\hline Field capacity of the soil & FC & $100 \mathrm{~mm}$ & Chiron (2005) \\
\hline Actual evapotranspiration per ha of wetland area & $\eta$ & $5 \mathrm{~mm} / \mathrm{ha}$ & Burba et al. (1999) \\
\hline
\end{tabular}

The model is specified and solved in the STELLA ${ }^{5}$ software, which is well suited for simulating dynamics of ecological-economic systems (Costanza and Gottlieb, 1998).

In system dynamic modeling, the ultimate objective of the validation process is to establish the structural validity of the model with respect to the modeling purpose. Confidence in the model simulation results is high only if the model has robust predictive ability in reproducing historical trends. Dynamic simulation models are validated by comparing model predicted versus observed past trends for selected variables. However, the validity tests should place emphasis on pattern prediction of key variables rather than point predictions, mainly because of the long-term orientation of these models (Güneralp and Barlas, 2003). Because of limited availability of observed time series data for most of the variables in the model, the validation exercise was done for a few variables for which past trend data could be obtained. The period used for validation was 1990 to 2006. After validating the model is used to conduct policy simulations for a 14 year post validation period, i.e. between 2006 and 2020.

Figs. 3 and 4 compare observed versus model predicted values for wetland converted to agriculture and social grant rate, respectively. Fig. 3 shows that wetland area converted to agriculture has been increasing with corresponding decrease in total wetland area and this has been primarily driven by increasing frequency of droughts which increases wetland conversion rates.

The predicted social grant rate follows an increasing trend in line with the observed trend due to increasing inflation (Fig. 4). Whilst the model predicted values are not exactly equal to the observed values in both cases, the model does well in predicting the observed pattern of these two variables. The correlation between model predicted and observed values is more than 0.9 in both cases suggesting that the model can be used with confidence.

Clearly it would be possible to establish a much stronger case if more numerical time series data were available for more variables in the model. Lack of past trend data on most variables severely restricted our validation options and collecting new dynamic data necessitates long time periods. However, it should be kept in mind that the main purpose of this model is to capture broad dynamic behaviour patterns of the real system, not provide point predictions.

\section{Simulation of Impacts of Alternative Wetland Management and Policy Regimes}

The first step in performing a simulation experiment is to run the baseline scenario which becomes the benchmark against which simulated scenarios are compared. Our scenario simulations are

\footnotetext{
${ }^{5}$ The STELLA model code is not presented for space considerations but is available upon request.
}

performed by changing values of exogenous variables in the model (Table 4) and comparing the outcomes with the base scenario.

Policy scenarios considered for simulations are selected on the basis of possible government policy interventions. The policy scenarios simulated include tax and subsidy policy regimes that work through changing effective prices of agricultural outputs, inputs, and market goods; as well as government policy instruments such as direct income

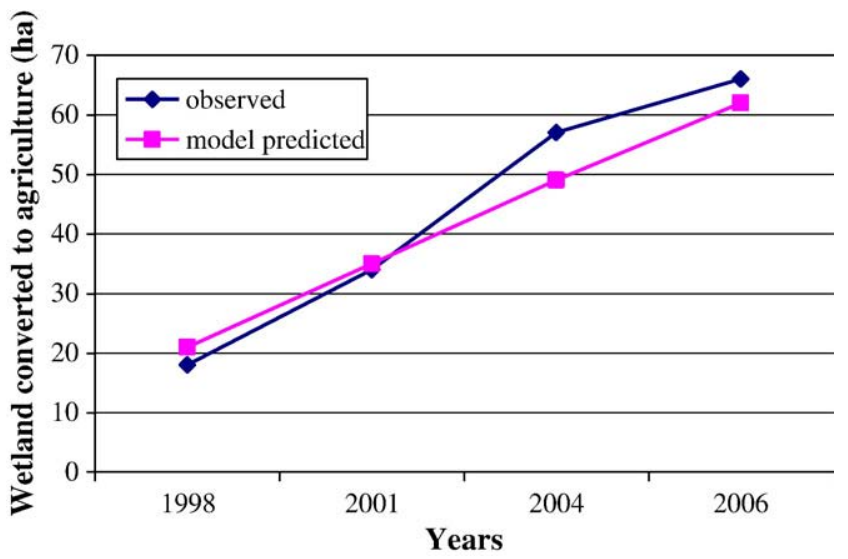

Fig. 3. Comparison of model predicted and actual wetland area converted to agriculture. Observed data obtained from Sarron (2005) and Adekola (2007).

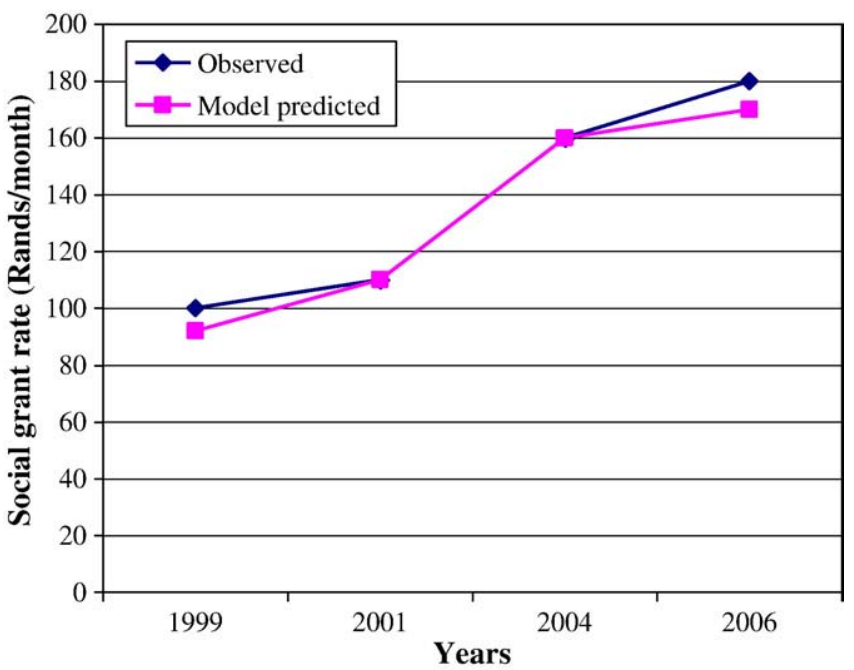

Fig. 4. Comparison of model predicted versus actual social grant rate. Observed data obtained from National Treasury (2008). 
Table 4

Definition of exogenous variables in the model.

\begin{tabular}{lll}
\hline Symbol & Definition of variable & Units \\
\hline $\mathrm{P}_{\mathrm{t}}$ & Precipitation at time $\mathrm{t}$ & Millimetres \\
$\mathrm{IS}_{\mathrm{t}}$ & Irrigation scheme seepage to wetland at time $\mathrm{t}$ & Millimetres \\
$\mathrm{Y}_{\mathrm{m}}$ & Maximum grain yield & Tons $/$ ha \\
$\mathrm{ET}_{\mathrm{m}}$ & Maximum crop evapotranspiration per season & Millimetres \\
$\mathrm{W}_{\mathrm{t}}$ & Wage rate at time $\mathrm{t}$ & Rands $/ \mathrm{h}$ \\
$\mathrm{P}_{\mathrm{G}, \mathrm{t}}$ & Price of grain at time $\mathrm{t}$ & Rands $/ \mathrm{kg}$ \\
$\mathrm{P}_{\mathrm{H}, \mathrm{t}}$ & Price of wetland biomass at time $\mathrm{t}$ & Rands $/ \mathrm{kg}$ \\
$\mathrm{P}_{\mathrm{M}, \mathrm{t}}$ & Price of market goods at time $\mathrm{t}$ & Rands $/ \mathrm{kg}$ \\
$\mathrm{P}_{\mathrm{X}, \mathrm{t}}$ & Price of agricultural inputs at time t & Rands $/ \mathrm{kg}$ \\
$\mathrm{P}_{\mathrm{W}, \mathrm{t}}$ & Price of water at time $\mathrm{t}$ & Rands $/ \mathrm{mm}$ \\
$\mathrm{NS}_{\mathrm{t}}$ & Number of social grants beneficiaries at time $\mathrm{t}$ & Number of people \\
$\mathrm{GDP}_{\mathrm{k}, \mathrm{t}}$ & GDP per capita at time $\mathrm{t}$ & Rands $/ \mathrm{capita}$ \\
$\mathrm{CPI}_{\mathrm{t}}$ & Consumer price index at time t & Index \\
\hline
\end{tabular}

transfers and changes in availability of off-farm work which are driven by changes in social policy and economic growth trends.

In order to maintain a functional wetland ecosystem in which biodiversity protection is maximal it is necessary to put part of the wetland area under protection. However, total protection is not always necessary in order to maintain high level of diversity, but would be necessary if the goal is to maintain an ecosystem intact in its natural state which in most cases is done for promoting ecotourism. In our simulation experiments we considered a scenario of partial protection through placing some percentage of the wetland under conservation.

Although climate change predictions for precipitation are less consistent, most simulations for southern Africa indicate that rainfall will decline in the next 100 years. Predictions for 2050 show that rainfall in southern Africa could be 10-20\% lower than the 1950-2000 averages (Reid et al., 2007). Based on these predictions, we consider a scenario of a $10 \%$ reduction in annual precipitation in our simulation experiments.

To evaluate social desirability of simulated intervention scenarios we compare final outcome values (values at the end of the simulation period which is year 2020) for selected indicators with the baseline scenario as done in other studies (Eppink et al., 2004; Saysel et al., 2002). As the primary purpose of this study is to investigate the impacts of alternative policy regimes on wetland functioning, ecosystem services and human well-being the key variables considered in our evaluations are: (1) wetland crop (grain) production and harvested biomass and their values (the two wetland services considered in the model), (2) total wetland area and total biomass stock (indicators of wetland conservation status), (3) wetland soil water content and groundwater level (indicators of wetland hydrological regulation services) and (4) net income per capita (a proxy for human well-being). The specific policy scenarios evaluated and results of the simulation experiments are given in Table 5.
A total of eight policy experiments have been simulated. Simulation results show that taxing wetland conversion to agriculture through reduced grain output prices (scenario 1 ) weakens the incentive for expanding area cultivated in the wetland leading to decreases in wetland crop production. This leads to an increase in total wetland area and thus lower evapotranspiration from cultivated land (crop water use), reducing total evapotranspiration from the system. As a result soil water content in the wetland increases lifting wetland groundwater level as recharge to groundwater is increased. In response, the intrinsic growth rate of wetland biomass increases (Eq. (14)) causing an increase in wetland biomass per hectare.

Total biomass stock is consequently higher due to increases in intrinsic growth rate of biomass and total wetland area and the number of biomass harvesters increases as a result. Net income per capita decreases due to the substantial reduction in the net value of grain production which by far exceeds the increase in net value of biomass harvested. In a nutshell, taxing grain output production discourages wetland conversion to agriculture which negatively impacts human well-being to the advantage of maintaining wetland ecological integrity.

Taxing excessive harvesting of biomass (scenario 2) through lower products' prices reduces total biomass harvested and increase biomass stock. Total wetland grain supply increases (Eq. (6)) causing an increase in crop water use $\left(\mathrm{ET}_{\mathrm{a}}\right)$ with consequent reductions in soil water content and wetland groundwater level. Although the reduction in groundwater level reduces natural wetland biomass growth (Eq. (14)), total biomass stock increases due to a reduction in total biomass harvested. Net value of harvested biomass decreases substantially due to a reduction in total harvested biomass. On the other hand, the incentive for grain production improves leading to higher conversion of wetland area for agriculture, which in turn causes net income per capita to increase.

These results demonstrate the trade-offs that need to be managed between improving human well-being in the short-run and conserving the wetland ecosystem (long-term sustainability goals), and between supply of the two wetland services (crop production and biomass harvesting) competing for water, labour and land resources.

A combined tax on both grain and biomass products (scenario 3 ) is found to be more effective in conserving the wetland and maintaining hydrological integrity than levying separate taxes on biomass and grain production. This of course comes at a higher welfare cost.

An alternative way of taxing wetland conversion is through increasing agricultural input price (scenario 4 ) which has similar but stronger effects compared to increasing grain prices. It increases agricultural production costs and reduces returns to agricultural production and therefore reduces the rate of conversion of wetland to cultivated agriculture. As can be seen from Table 5, much higher growth in total wetland area obtains under the input price policy interventions than with the grain price tax policy (scenario 1). Also

Table 5

Change in values of selected indicator variables, expressed as percentages of baseline values.

\begin{tabular}{|c|c|c|c|c|c|c|c|c|c|}
\hline \multicolumn{10}{|c|}{$\%$ Change in indicator variables compared to their baseline levels } \\
\hline Policy scenarios & $\begin{array}{l}\text { Total } \\
\text { biomass } \\
\text { harvested } \\
\text { (tons) }\end{array}$ & $\begin{array}{l}\text { Total } \\
\text { biomass } \\
\text { stock } \\
\text { (tons) }\end{array}$ & $\begin{array}{l}\text { Total wetland } \\
\text { grain supply } \\
\text { (tons) }\end{array}$ & $\begin{array}{l}\text { Wetland } \\
\text { ground } \\
\text { water level } \\
(\mathrm{m})\end{array}$ & $\begin{array}{l}\text { Wetland soil } \\
\text { water content } \\
(\mathrm{mm} 3)\end{array}$ & $\begin{array}{l}\text { Net value of } \\
\text { wetland grain } \\
\text { (Rands) }\end{array}$ & $\begin{array}{l}\text { Net value of } \\
\text { harvested } \\
\text { biomass } \\
\text { (Rands) }\end{array}$ & $\begin{array}{l}\text { Total } \\
\text { wetland } \\
\text { area (ha) }\end{array}$ & $\begin{array}{l}\text { Net income per } \\
\text { capita (Rands/ } \\
\text { capita/year) }\end{array}$ \\
\hline (1) Taxing grain production ( $30 \%$ on price) & 0.11 & 0.04 & -0.01 & 0.26 & 0.01 & -10.06 & 4.29 & 0.43 & -0.21 \\
\hline (2) Taxing biomass products ( $30 \%$ on price) & -0.11 & 0.06 & 0.01 & -0.01 & -0.01 & 0.04 & -17.79 & -0.12 & 0.02 \\
\hline $\begin{array}{l}\text { (3) Combined tax on grain and biomass } \\
\text { (30\% each) }\end{array}$ & -0.85 & 0.15 & -0.01 & 0.45 & 0.07 & -10.07 & -10.15 & 0.46 & -0.23 \\
\hline (4) $30 \%$ Increase in agric input prices ${ }^{a}$ & 0.12 & 0.14 & -0.21 & 1.76 & 5.1 & -0.19 & 3.6 & 1.15 & -0.28 \\
\hline (5) $30 \%$ Increase in the off-farm wage rate & -0.55 & 0.01 & -0.01 & 0.04 & 0.01 & -39.58 & -26.65 & 0.14 & 6.59 \\
\hline $\begin{array}{l}\text { (6) Increased availability of off-farm opportunities } \\
\text { ( } 5 \% \text { increase in GDP per capita) }\end{array}$ & 0.10 & 0.29 & -0.81 & 0.27 & 1.42 & -0.01 & 0.03 & 2.72 & 6.40 \\
\hline (7) Putting $30 \%$ of wetland area under protection & -0.22 & 38.63 & -22.45 & 0.06 & 43.77 & -22.45 & -0.45 & 92.98 & -0.46 \\
\hline (8) $10 \%$ Reduction in precipitation & -0.89 & -33.01 & 1.60 & -0.91 & -13.6 & -4.10 & -2.24 & -76.58 & -0.13 \\
\hline
\end{tabular}

a Price of maize seed is used as this is the key variable input used in wetland grain production. 
much larger impacts on water levels and wetland hydrology are realized. This however comes at higher losses in economic welfare measured in net income per capita. The above results suggest that, while policy interventions such as agricultural price support policies (e.g. subsidies) have the potential to improve the welfare of poor rural farmers they also lead to agricultural intensification and environmental degradation.

Like taxing prices of other inputs, intervention through the urban wage rate policy instrument (scenario 5 ) reduces wetland grain supply (Eq. (6)) and its value. Improving off-farm wages however, results in substantial decreases in production and net value of harvested biomass since labour is the main input in biomass harvesting and hence the high sensitivity to movements in wages. Despite this, net income per capita increases due to a substantial increase in the off-farm income (Eq. (30)) component of total net income (Eq. (35)). At the same time the wage rate option achieves conservation objectives but at lower levels compared to commodity price (tax/subsidy) regimes. This makes clear the importance of understanding the important distinctions carefully weighing potential net impacts of alternative policy intervention choices and instruments.

Wetland area and net income per capita grow by the highest percentage with increased off-farm income opportunities (scenario 6). This result derives from the fact that increasing in off-farm income opportunities (through increasing GDP per capita) causes an increase in the emigration rate (Eq. (26)). This leads to reduction in the population which in turn reduces the rate of wetland conversion to agriculture as demand for land and food is reduced. Accordingly, wetland grain supply and net value of grain decline. Income from offfarm employment opportunities increases as the number of households engaged in off-farm work increases. The increase in off-farm income totally offsets reductions in net value of harvested biomass and grain resulting in a significant increase in net income per capita. Like improved off-farm wages this scenario has a double dividend effect as it simultaneously improves economic well-being and conserves the wetland ecosystem.

This result demonstrates the potential for indirect economic incentive measures such as improving off-farm employment and income opportunities to contribute towards improving both human well-being and wetland conservation. However, as demonstrated by Brandon and Wells (1992) and Ferraro and Kramer (1997) such measures do not automatically lead to sustainable resource management and in some cases the availability of alternative income sources leads to intensification of resource use activities. For alternative livelihood and income sources to spur conservation of wetland resources, it is important to emphasize the overall economic development in the area to increase availability of off-farm employment opportunities outside of the natural-resources or agriculture-based economy. Promoting livelihood diversification out of agriculture becomes an important strategy for enhancing sustainable wetland management.

The results of the wetland conservation strategy (scenario 7) show that economic well-being of the local population declines considerably due to substantial reductions in the value of biomass harvested and grain produced under wetland as harvesting of natural products and conversion of wetland to cropland are restricted. However, the reduction in the economic welfare to the local community only takes into account direct use benefits of the wetland without considering its non-use values and indirect benefits of maintaining biodiversity intactness and hydrological regulation services.

The predicted reduction in precipitation (scenario 8) produces by far the worst results in terms of conserving the wetland. Wetland area declines by close to $90 \%$ due to an increased rate of conversion of the wetland to cultivation as rainfall declines. The rate of wetland conversion to cultivation increases as more households move into the wetland due to its ability to retain soil moisture throughout the year. As a consequence, area under cultivation in the wetland system expands and total wetland area declines accordingly. Reduction in precipitation adversely affects wetland soil moisture content and groundwater level, which in conjunction with the recession of the total wetland area leads to a reduction in total biomass.

\section{Conclusions and Policy Implications}

The purpose of this paper was to analyze the impacts of various management and policy regimes on wetland functioning and economic well-being. A dynamic ecological-economic model based on systems' dynamics framework was developed and applied to quantify the impacts of potential management and policy intervention options on the wetland system under study.

Results of the policy simulations suggest that wetland direct use (provisioning) services (crop production and natural resource harvesting) are inter-linked with subtle trade-offs involved through their competition for labour, land and water resources. Some policy interventions such as improving profitability of cultivation through supporting agricultural output prices and/or subsidizing input prices may improve economic well-being but at the expense of wetland conservation.

Results also suggest that increasing off-farm income and employment opportunities has a double dividend effect because it simultaneously improves economic well-being and enhances wetland conservation. Therefore, promoting livelihood diversification out of agriculture becomes an important strategy for enhancing sustainable wetland management. Livelihood diversification can be supported through increased government investment in rural infrastructure, downstream value chains, health and education.

A pure conservation strategy that aims at protecting the wetland leads to substantial reductions in economic welfare of the local population unless their livelihood sources are diversified into alternative non-farm employment and income options. This study also confirms that the predicted reduction in rainfall in southern Africa is likely to accelerate wetland conversion to agriculture and undermine wetland conservation efforts. Therefore, improving the capacity of rural farmers to adapt to climate change, especially drought is important to reduce pressure on wetland resources. Strategies that reduce dependence on wetlands for agriculture such as investment in water harvesting and storage, efficient irrigation methods, and promoting use of drought tolerant crops and diversifying out of agriculture should therefore be promoted.

Although the dynamic simulation model we developed generated useful results and policy insights for wetland management, in future there is need to fill data gaps and improve our understanding of several feedback mechanisms within the system. For example, it is important to go beyond the two wetland services considered in this study (crop production and biomass harvesting) and include bundles of multiple provisioning and regulating services. In addition, there is also room for improving the model to take into consideration other wetland management strategies not considered here.

\section{Acknowledgment}

This research paper was carried out as part of the Challenge Program Project (CP30) entitled: Wetlands-based livelihoods in the Limpopo basin: balancing social welfare and environmental security. The financial support from the Challenge Program is gratefully acknowledged. Additional research funding was obtained from START under its African doctoral fellowship program. We acknowledge the contribution of Sylvie Morardet, Mutsa Masiyandima and Dinis Juizo in the development of components of the model. Finally, we would like to thank two anonymous reviewers for their comments on an earlier draft. 


\section{Appendix A. The full system of equations showing the linkages between modeled ecological-economic systems}

Hydrology Module, i Refers to Wetland (w) or Irrigation System ( $r$ )

Total evapotranspiration $(\mathrm{mm})$ :

$E T_{t}^{\mathrm{i}}=E T c_{t}^{\mathrm{i}}+E T v_{t}^{\mathrm{i}}$

Actual crop evapotranspiration from cultivated area $(\mathrm{mm})$ :

$E T C_{t}^{\mathrm{i}}=E T_{\mathrm{a}, t}^{\mathrm{i}} * A C_{t}^{\mathrm{i}}$.

Actual evapotranspiration from natural vegetation $(\mathrm{mm})$ :

$E T_{\mathrm{v}}^{\mathrm{w}}=\eta * T A_{t}^{\mathrm{w}}$

Change in wetland water storage $(\mathrm{w}=$ wetland $)\left(\mathrm{mm}^{3}\right)$ :

$\Delta S^{\mathrm{w}}=P_{t}+I S_{t}-G S_{t}-E T_{t}^{\mathrm{w}}$.

Wetland soil water content ( $\mathrm{w}=$ wetland) $(\mathrm{mm})$ :

$M C_{t+1}-M C_{t}=P_{t}+C R_{t}-G S_{t}-E T_{t}^{\mathrm{w}}$.

Wetland groundwater level (m):

$G W L_{t+1}=G W L_{t}+\left(M C_{t}-F C\right) / 10^{4}$.

Crop Production Module

Actual crop yield (tons/ha):

$Y_{\mathrm{a}}^{\mathrm{i}}=Y_{\mathrm{m}}^{\mathrm{i}}\left[1-k_{\mathrm{y}} *\left(1-E T_{\mathrm{a}}^{\mathrm{i}} / E T_{\mathrm{m}}^{\mathrm{i}}\right)\right]$.

Household grain supply function ( $\mathrm{kg} /$ household/year):

$G_{q, t}=\alpha_{0}+\alpha_{1} E_{t}+\alpha_{2} W_{t}+\alpha_{3} P_{\mathrm{G}, t}+\alpha_{4} P_{\mathrm{H}, t}+\alpha_{5} P_{\mathrm{M}, t}+\alpha_{6} P_{\mathrm{X}, t}$.

Household labour used in grain production (hours/household/year):

$L_{\mathrm{G}, t}=\beta_{0}+\beta_{1} E_{t}+\beta_{2} W_{t}+\beta_{3} P_{\mathrm{G}, t}+\beta_{4} P_{\mathrm{H}, t}+\beta_{5} P_{\mathrm{M}, t}+\beta_{6} P_{\mathrm{X}, t}$.

Total grain supply (tons):

$T G_{t}^{\mathrm{i}}=\sum_{q=1}^{Q_{\mathrm{i}}} G_{q, t}^{\mathrm{i}}$

Area cultivated (ha):

$A C_{t}^{\mathrm{i}}=\sum_{q=1}^{Q_{\mathrm{i}}} A_{q, t}^{\mathrm{i}}$

Average yield (tons/ha):

$Y_{\mathrm{a}, t}^{\mathrm{i}}=\frac{T G_{t}^{\mathrm{i}}}{A C_{t}^{\mathrm{i}}}$

Net value of grain (Rands):

$R_{t}=A C_{t}^{\mathrm{i}}\left(P_{\mathrm{G}, t} \sum_{\mathrm{i}} Y_{\mathrm{a}, t}^{\mathrm{i}}-P_{\mathrm{W}, t} \sum_{\mathrm{i}} E T_{\mathrm{a}}^{\mathrm{i}}\right)-W_{t} * L_{\mathrm{G}, t} * \sum_{\mathrm{i}} Q_{\mathrm{i}}$.

${ }^{6}$ This equation is captured as a logical function using if-then-else statements in STELLA to capture the fact that recharge to groundwater only occurs if MCt $>\mathrm{FC}$ else its equal to zero. We divide $(\mathrm{MCt}-\mathrm{FC})$ by 104 to convert it from millimetres to metres since GWL is measured in metres.

\section{Land Use Module}

Total wetland area (ha):

$T A_{t+1}^{\mathrm{w}}=T A_{t}^{\mathrm{w}}-A C_{t}^{\mathrm{w}}$

Area of wetland converted to cultivation (ha):

$A C_{t}^{\mathrm{w}}=a_{1} P_{t}+a_{2} P_{\mathrm{G}, t}+a_{3} P_{\mathrm{X}, t}+a_{4}$ Pop $_{t}$

Natural wetland vegetation module

Biomass per ha (tons/ha):

$B_{t+1}-B_{t}=r_{t} B_{t}\left(1-B_{t} / k_{\mathrm{B}}\right)$

Intrinsic growth rate:

$s_{t}=\mu_{0}+\mu_{1} G W L_{t}$.

Actual growth rate:

$r_{t}=s_{t}^{*} \sigma_{t}$

Growth rate multiplier:

$\sigma_{t}=\operatorname{GRAPH}\left(B_{t} / \operatorname{INITIAL}\left(B_{t}\right)\right) ; 0<\sigma_{t}<1$.

Total biomass stock (tons):

$T B_{t}=T A_{t}^{\mathrm{w}} * B_{t}-h_{t}$

Total biomass harvested (tons):

$h_{t}=N H_{t} * X_{\mathrm{H}, t}^{\mathrm{H}}$

Number of biomass harvesting households:

$N H_{t}=c * T B_{t}$

Household biomass supply function (tons/household/year):

$X_{\mathrm{H}, t}^{\mathrm{H}}=\theta_{0}+\theta_{1} E_{t}+\theta_{2} W_{t}+\theta_{3} P_{\mathrm{G}, t}+\theta_{4} P_{\mathrm{H}, t}+\theta_{5} P_{\mathrm{M}, t}+\theta_{6} P_{\mathrm{X}, t}$.

Labour cost for biomass harvesting (Rands):

$b_{t}=W_{t} * L_{\mathrm{H}, t} * N H_{t}$.

Household labour used in biomass harvesting (hours/household/ year):

$L_{\mathrm{H}, t}=\rho_{0}+\rho_{1} E_{t}+\rho_{2} W_{t}+\rho_{3} P_{\mathrm{G}, t}+\rho_{4} P_{\mathrm{H}, t}+\rho_{5} P_{\mathrm{M}, t}+\rho_{6} P_{\mathrm{X}, t}$.

Net value of harvested biomass (Rands):

$V_{t}=h_{t} * P_{H, t}-b_{t}$

Economic Well-being Module

Population (no. of people):

$\operatorname{Pop}_{t+1}=\operatorname{Pop}_{t}(1+g)-E M_{t}$. 
Number of emigrants (no. of people):

$E M_{t}=e_{t} * P_{0}$

Emigration rate:

$e_{t}=f_{0}+f_{1} G D P_{\mathrm{k}, t}+f_{2} P_{t}$

Total labour supply (hours/year):

$L S_{t}=\left(\kappa_{1} m_{1}+\kappa_{2} m_{2}\right) *$ Pop $_{t}$

Total labour used in livelihood activities (hours/year):

$L D_{t}=L_{0, t} * N O_{t}+L_{\mathrm{H}, t} * N H_{t}+L_{\mathrm{G}, t} * \sum_{\mathrm{i}} Q_{\mathrm{i}}$

Labour market equilibrium:

$L S_{t}=L D_{t}$

Off-farm income (Rands/year):

$O_{t}=N O_{t} * W_{t} * L_{0, t}$

Household labour used in off-farm work (hours/household/year):

$L_{\mathrm{o}, t}=\delta_{0}+\delta_{1} E_{t}+\delta_{2} W_{t}+\delta_{3} P_{\mathrm{G}, t}+\delta_{4} P_{\mathrm{H}, t}+\delta_{5} P_{\mathrm{M}, t}+\delta_{6} P_{\mathrm{X}, t}$.

Number of households engaged in off-farm work (households):

$N O_{t}=d_{0}+d_{1} G D P_{\mathrm{k}, t}$.

Exogenous income (Rands/year):

$E_{t}=z_{t} * N S_{t}$

Social grant rate (Rand/beneficiary/year):

$z_{t}=k_{0}+k_{1} C P I_{t}$

Total net income (Rands/year):

$N I_{t}=R_{t}+V_{t}+O_{t}+E_{t}$.

Economic well-being (Rands/capita):

$S W_{t}=\frac{N I_{t}}{P o p_{t}}$

\section{References}

Adekola, O., 2007. Economic valuation and livelihood analysis of the provisioning services provided by Ga-Mampa wetland, South Africa. Unpublished master's thesis. Wageningen University.

Biggs, R., et al., 2004. Nature supporting people. The Southern African Millennium Ecosystem Assessment (SAFMA) Integrated Report. A Contribution to the Millennium Ecosystem Assessment.

Brandon, K.E., Wells, M., 1992. Planning for people and parks: design dilemmas. World Development 20 (4), 557-570.

Wetlands conservation and management in southern Africa: challenges and opportunities, summary of the SADC wetlands conservation survey reports. In: Breen, C.M. Quinn, N.W., Mander, J.J. (Eds.), IUCN Wetlands Programme.

Burba, G.G., Verma, S.B., Kim, J., 1999. Surface energy fluxes of phragmites australis in prairie wetland. Agricultural and Forestry Meteorology 94, 31-51.

Bullock, A., Acreman, M., 2003. The role of wetlands in the hydrological cycle. Hydrology \& Earth System Sciences 7 (3), 358-389.

Chiron, D., 2005. Impact of the small-scale irrigated sector on household revenues of the black community of Ga-Mampa Valley (Ward of Mafefe). Contribution to the Irrigation Management Transfer Study of the Small-scale Irrigation Schemes. Limpopo Province - South Africa, Master of Science, CNEARC.

Chopra, K., Adhikari, S.K., 2004. Environment development linkages: modelling a wetland system for ecological and economic value. Environment and Development Economics 9 (1), 19-45.
Costanza, R., Gottlieb, S., 1998. Modelling ecological and economic systems with STELLA: part II. Ecological Modelling 112 (2-3), 81-84.

Department of Agriculture, 2009. Abstract of Agricultural Statistics. Republic of South Africa, Directorate of Agricultural Statistics.

Doorenbos, Kassam, A.H., 1979. Yield Response to Water. Irrigation and Drainage Paper 33. FAO, Rome.

Durand, W., 2008. Estimating crop water use for 19 Water Management Areas of South Africa using CROPWAT, unpublished CEEPA project report, CEEPA, University of Pretoria.

Eppink, F.V., van den Bergh, J.C.M., Rietveld, P., 2004. Modelling biodiversity and land use: urban growth, agriculture and nature in a wetland area. Ecological Economics 51, 201-216.

Ferraro, P.J., Kramer, R.A., 1997. Compensation and Economic Incentives: Reducing Pressure on Protected Areas. Oxford University Press, Oxford, UK.

Finlayson, C.M., Moser, M. (Eds.), 1991. Wetlands: A Global Perspective. Facts on File, Oxford.

Forrester, J.W., 1968. Principles of Systems. Productivity Press, Cambridge, MA

Frenken, K., Mharapara, I., 2002. Wetland development and management in SADC countries. Proceedings of a Sub-regional Workshop Held in Harare, Zimbabwe, 19-23 November, 2001

Güneralp, B., Barlas, Y., 2003. Dynamic modelling of a shallow freshwater lake for ecological and economic sustainability. Ecological Modelling 167 (1-2), 115-138.

Hellden, U., 2008. A coupled human-environment model for desertification simulation and impact studies. Global and Planetary Change 64, 158-168.

Higgins, S.I., Turpie, J.K., Costanza, R., Cowling, R.M., Le Maitre, D.C., Marais, C., Midgley, G.F., 1997. An ecological-economic simulation model of mountain fynbos ecosystems: dynamics, valuation and management. Ecological Economics 22, 155-169.

Jogo, W., 2009. Managing the trade-off between conservation and exploitation of wetland services for economic well-being: the case of the Limpopo wetland in southern Africa. Unpublished PhD thesis. University of Pretoria, RSA.

Kotze, D. C.,2005. An ecological assessment of the health of the Mohlapetsi wetland, Limpopo Province. South Africa: Centre for Environment, Agriculture and Development, University of KwaZulu-Natal.

Kotze, D.C., Breen, C.M., Quinn, N., 1995. Wetland losses in South Africa. In: Cowan, G.I. (Ed.), Wetlands of South Africa. Dept. of Environmental Affairs and Tourism, Pretoria, S. Africa, pp. 263-272.

Matiza, T., Chabwela, H.N., 1992. wetlands management: a critical issue for conservation in Africa. Wetlands Conservation Conference for Southern Africa. IUCN, Mavuti.

McCartney, M.P., 2005. Technical Note: Hydrology of the Mohlapitsi Catchment. International Water Management Institute (IWMI), Pretoria.

National Treasury of South Africa (2008) Provincial Budgets and Expenditure Review: 2001/02-2007/08, Chapter 4: Social development, www.finance.gov.za.

Portela, R., Rademacher, I., 2001. A dynamic model of patterns of deforestation and their effect on the ability of the Brazilian Amazonia to provide ecosystem services. Ecological Modelling 143 (1-2), 115-146.

Reid, H., Sahlen, L., MacGregor, J., Stage, J.,2007. The economic impact of climate change in Namibia. Discussion Paper 07-02. International Institute for Environment and Development, Environmental Economics Programme.

Sarron, C., 2005. Effects of wetland degradation on the hydrological regime of a quaternary catchment in the Mohlapitsi River, Ga-Mampa valley. Unpublished Masters thesis. Cecole Nationale Supérieure Agronomique de Rennes.

Saysel, A.K., Barlas, Y., Yenigun, O., 2002. Environmental sustainability in an agricultural development project: a system dynamics approach. Journal of Environmental Management 64 (3), 247-260.

Schuyt, K.D., 1999. Economic valuation of the Lake Chilwa wetland. Report for the Lake Chilwa Wetland and Catchment Management Project.

Seyam, I.M. Hoekstra, A.Y. Ngabirano, G.S Savenije, H.H.G, 2001. The value of freshwater wetlands in the Zambezi Basin. AWRA/IWLRI - University of Dundee International Specialty Conference. Dundee.

Statistics South Africa, 2004. Census 2001: Primary Tables Limpopo, Statistics South Africa, Pretoria.

Stephenne, N., Lambin, E.F., 2001. A dynamic simulation model of land-use changes in Sudano-sahelian countries of Africa (SALU). Agriculture, Ecosystems \& Environment 85 (1-3), 145-161.

Tarr, J.A., Van Rooyen, M.W., Bothma, J.P., 2004. The response of phragmites australis to harvesting pressure in the Muzi swamp of the Tembe elephant park, South Africa. Land Degradation and Development 15, 487-497.

Taylor, A.R.D., Howard, G.W., Begg, G.W., 1995. Developing wetland inventories in southern Africa: a review. Vegetatio 118 (1-2), 57-79.

Thenya, T., 2006. Analysis of macrophyte biomass productivity, utilization and its impact on various eco-types of Yala Swamp, Lake Victoria Basin, Kenya. Ecology and Development Series No 48.

Turpie, J., Smith, B., Emerton, L., Barnes, J., 1999. Economic value of the Zambezi Basin wetlands. IUCN Regional Office for Southern Africa. Zambezi Basin Wetlands Conservation and Resource Utilization Project.

van Beukering, P.J.H., Cesar, H.C., Janssen, M.A., 2003. Economic valuation of the Leuser National Park on Sumatra, Indonesia. Ecological Economics 44 (1), 43-62.

Wickins, P. 1981. The Natives Land Act of 1913: a cautionary essay on the simple explanation of complex change. South African Journal of Economics 49 (2), 65-89.

Woodwell, J.C., 1998. A simulation model to illustrate feedbacks among resource consumption, production, and factors of production in ecological-economic systems. Ecological Modelling 112 (2-3), 227-248.

World Resources Institute. (2003). Watersheds of Africa: A06, Limpopo (available at www.earthtrends.wri.org). 